\title{
SELECTED SYSTEMIC CONCLUSIONS OF PATENT ANALYSIS ON NANOTECHNOLOGY IN THE EU-28
}

\author{
[Vybrané systémové závery patentovej analýzy nanotechnológií v EÚ-28]
}

\author{
Marek Jemala ${ }^{1}$, Lubomír Jemala ${ }^{2}$ \\ ${ }^{1}$ Ústav priemyselného inžinierstva a manažmentu, MTF STU, Paulínska 16, 91724 Trnava \\ Email: marek.jemala@stuba.sk
}

${ }^{2}$ Oddelenie ekonomiky a manažmentu podnikania, Ústav manažmentu STU, Vazovova 5, 81243 Bratislava Email: lubomir.jemala@stuba.sk

\begin{abstract}
Certain fundamentals of the nanotechnology (NT) discipline can be already found in 1870, when two professors Elihu Thomson and Edwin Houston experimented and later patented inventions on the existing arc lamps and dynamo design. The emergence of NT as a new scientific discipline can be found a hundred years later and it is also connected with the invention of the scanning tunneling microscope and the discovery of fullerenes. Among the first companies that patented NT were: General Electric, Unisys, Honeywell, DuPont, Bell Labs, and IBM. Among the first patenting areas of NT were: nano-materials, nano-manufacturing and nano-interactions. This scientific study has two particular goals. Methodological part (Chapter 1 and 2) provides a clear insight into selected topical issues of patenting, searching and categorization of NT. This part is often overlooked/simplified in many scientific papers on NT, which brings a lot of uncertainty for this discipline. The second part is the systemic analysis (Chapter 3 ) that is to provide a clear insight into the patented NT in the EU, based on the comprehensive statistics of the European database of EPO patents (1940-2015). But, the main scientific goal of this study is to make some conclusions for the promotion of innovation and patenting NT in the EU.
\end{abstract}

Keywords: European nanotechnology patents, Nanotechnology, Patenting nanotechnology, Searching and categorization of nanotechnology.

JEL classification: $\mathrm{O} 31, \mathrm{O} 32, \mathrm{O} 34, \mathrm{O} 52$

Doručeno redakci: 30.3.2015; Recenzováno: 10.4.2015; 5.5.2015; Schváleno k publikování: 23.9.2015

\section{1 Úvod do problematiky patentovania nanotechnologií}

V prvej časti tejto štúdie by sme sa stručne zamerali na definíciu problematiky NT, ako vedenej disciplíny, hlavný význam patentu, delenie nanotechnologických patentov a vybrané problémy patentovania NT.

V roku 1959, Americký fyzik Richard Feynman prezentoval svoju prednášku s názvom "There's Plenty of Room at the Bottom" na výročnej schôdzi Americkej fyzikálnej spoločnosti na pôde California Institute of Technology. V tejto slávnej prednáške, Feynman položil koncepčné základy pre oblast', ktorú nazývame nanotechnológie. V tom čase boli nanotechnológie prevažne teoretickým technologickým konceptom. O 25 rokov neskôr, Feynman aktualizoval svoju prednášku a ukázal, aké technologické pokroky boli vykonané od tej doby a prvýkrát načrtol svoju víziu pre "nano svet". (Caltech, 2015) V súčasnej dobe neexistuje jednotná definícia toho, čo presne nanotechnológie (NT) sú, pretože NT majú interdisciplinárny charakter (JRC, 2013). Rastúci záujem o NT a rastúci počet nanotechnologických inovácí a patentov prinášajú otázku, čo robí NT také atraktívne? NT sa často používajú vo význame: technológie s nano-vel'kost’ou/ nano-rozmerom, ktoré sa týkajú kontrolovaných geometrických tvarov, procesov a vel'kostí pod 100 nanometrov $(\mathrm{nm}) \mathrm{v}$ jednej alebo viacerých veličinách (Drexler, 1996). Pričom nano-štruktúra znamená objekt, ktorý má aspoň jednu funkčnú zložku v nano-vel'kosti, ktorá je fyzikálnou, chemickou, alebo 
biologickou vlastnost'ou a efektom, ktoré sú jednoznačne pripísané nano-rozmerom (UPVSR, 2013).

Patent slúži ako dôležitý nástroj pre kapitalizáciu inovačných investícií a know-how, získanie zákazníkov a trhového podielu, ochrana pred konkurenciou a dosiahnutie d'alších ciel'ov podniku. Z hl'adiska patentovania NT existujú dve hlavné formy patentov: úžitkové a dizajnové patenty (Holme, 2013). Úžitkové patenty majú chránit' inovatívne, dosial' nepoužívané, užitočné a bezpečné procesy, výrobky a technológie. Dizajnové patenty sú vydávané na ochranu ornamentálneho tvaru alebo konštrukcie určitého objektu. Celkovo exituje 6 hlavných odborov NT: iónové kanáliky, molekulárne zariadenia, nano-prístrojové vybavenie, nano-výroba, nano-elektronika a nanomateriály (Fiedler a Welpe, 2010). Patentové prihlášky v oblasti NT sú rovnomerne rozložené medzi technologické a produktové aplikácie. Vel'akrát je však t’ažké odlúčit' technológiu od konkrétneho výrobku. Nanomateriály, nano-IT, nano-výroba a v poslednej dobe aj nano-biotechnológie predstavujú najväčší počet vydaných patentov (Giachetti a Marchi, 2010). Patenty v oblasti NT pripravené individuálnymi vynálezcami sú zvyčajne pridelené organizácii, ktorá sa uchádza o patent. Produkcia viac ako $60 \%$ patentov ku nanotechnológiám je zabezpečená aktívnymi vedcami. Približne $70 \%$ patentov ku nanotechnológiám je vlastnená súkromnými spoločnost’ami. (Bonaccorsi a Thoma, 2007) Pozitívny vplyv návratnosti finančných zdrojov je väčší, ak patenty ku NT sú vo vlastníctve súkromných firiem, skôr než univerzít, výskumných ústavov, alebo kombinovaných aliancií (Wang a Guan, 2010). Zložitost' VaV v oblasti NT obvykle vyžaduje vytváranie spolupracujúcich tímov a viac ako $60 \%$ patentov ku NT bolo pridelených tímu vynálezcov (Jemala, 2010). Vynálezy v oblasti NT sú zvyčajne patentované spoločne s iným produktom alebo technológiou (Beaudry a Schiffauerova, 2011).

Mnoho patentov ku NT je poskytnutých iba na základný vynález, nie na výrobu komerčného výrobku. Vzhl'adom na zložitost' výskumu NT, tieto dve fázy majú spravidla rôznych vlastníkov, čo často vedie $\mathrm{k}$ problémom, pokial' ide o vlastníctvo patentu. Takto sú tieto patenty často podhodnotené (Wolf a Medikonda, 2012). Patentovatel'né duševné vlastníctvo (DV) ku NT je často $\mathrm{v}$ dvoch hlavných formách: výrobné metódy a výpočtové techniky (Jain a kol., 2011). Výrobné metódy zahŕňajú využitie presných a efektívnych výrobných postupov, ktoré umožnia výrobu materiálov, výrobkov a technológií $\mathrm{v}$ nanometroch. Výpočtové techniky umožňujú analyzovat', simulovat' a realizovat' výrobné postupy prostredníctvom simulácie miniaturizácie objektov. Toto vytvára nové možnosti pre výrobu, nové spôsoby konštrukcie a nové formy optiky alebo povrchovej úpravy.

Patenty v oblasti NT sú klasifikované triedami “B82Y” (EPO) a “Class 977” (USPTO). Predpokladá sa, že bolo vydaných príliš vel’a včasných patentov ku NT s príliš rozsiahlymi, nešpecifickými a prekrývajúcimi sa právami (Wartburg a Teichert, 2008). ${ }^{1} \mathrm{~V}$ EÚ, vel'ká skupina vedcov pracuje na podobných projektoch $\mathrm{v}$ oblasti NT, čo vedie $\mathrm{k}$ neefektívnosti a prekrývajúcim sa právam. Nárast patentovania NT tiež spôsobil tzv. patentové húštiny a bariéry pre úplnú ochranu $\mathrm{DV}^{2}$ Ako dôsledok, existuje vel'a protichodných patentov neurčitej platnosti, čo predstavuje riziko pre ich komercializáciu (Hicks a kol., 2010), ako aj pre d'alšie patentovanie NT. Pre výskumníka v oblasti NT existuje značné riziko, že vynájde

\footnotetext{
${ }^{1}$ Patentové právo popisuje nárok držitel’a patentu na špecifickú inováciu/vynález, aby sa zabránilo ostatným podnikatel'om komercializovat' túto inováciu. Ide o najdôležitejšiu čast' patentu, ktorá definuje rozsah vynálezu, ktorý je chránený patentom. Patentové právo je tiež ukazovatel’om kvality patentov.

${ }^{2}$ Patentové húštiny/bariéry môžu vzniknút', ak jeden výrobok zahŕňa niekol'ko patentov, čo môže mat' negatívny vplyv na $\mathrm{VaV}$, a to aj pri nižších transakčných nákladov, alebo vertikálnom monopole (Bessen, 2003). Bariéry ochrany DV sa môžu objavit', ak rôzne podniky majú v držbe niekol'ko súvisiacich práv duševného vlastníctva a tvrdia, že si delia súvisiace príjmy (Wartburg a Teichert, 2008).
} 
technológiu, ktorá môže porušit' iné patentové práva, alebo ktorú nemožno patentovat'. V rokoch 1980-1990 bol tento jav charakteristický pre odvetvie biotechnológií (Chamas, 2008). Všeobecne platí, že odvetvie NT a biotechnológií majú vel'mi porovnatel'né vzorce vlastného rozvoja. Ďalším problémom patentovanie NT je patentové meškanie. Jedná sa o množstvo nevybavených patentových prihlášok, ktoré boli podané a stále nepreskúmané. Priemerná dížka patentovania NT je 2,3 roka a viac ako $1,5 \%$ patentov má túto dobu dlhšiu ako 5 rokov, čo predstavuje značné riziko pre komercializáciu NT. Aby sa zabránilo zvýšeniu nekvalitných patentových prihlášok, EPO (Európsky patentový úrad) nedávno predstavil tzv. EPO Utilisation Scheme (schému efektívnosti). Táto schéma by mala zlepšit' účinnost' a kvalitu Európskeho patentového systému prostredníctvom užšej spolupráce národných patentových úradov EÚ a EPO (IPO.GOV, 2013). Rôznorodost' NT však volá po jednotnom rámci na ochranu práv DV spojeného s NT (Chamas, 2008). Aj ked' prax najznámejších patentových úradov ako sú USPTO, JPO, EPO, alebo WIPO prijala väčšina krajín vrátane SR a ČR. Rada pre konkurencieschopnost' EÚ potvrdila dôležitú úlohu NT v mnohých oblastiach, ako sú napríklad zdravotná starostlivost', informačné technológie, materiálové inžinierstvo, výroba, prístrojová technika, energia, životné prostredie, alebo bezpečnost' (SOVVA, 2013). Pre zvýšenie efektívnosti inovácií a patentovania v oblasti NT je potrebné vytvorit' jednotný systém evidencie realizovaného a prebiehajúceho $\mathrm{VaV} v$ krajinách EÚ, systematizovat' znalosti a skúsenosti v oblasti NT, a to aj v súvislosti so stratégiou inteligentnej špecializácie regiónov EÚ, odstraňovat' administratívnu a finančnú náročnost' patentovania NT, ale aj skrátit' trvanie tohto procesu/procesov.

\section{Vstup do problematiky vyhl'adávania a kategorizácie nanotechnologických patentov}

$\mathrm{V}$ druhej tiež metodickej kapitole tejto štúdie by sme sa zamerali na hlavnú problematiku vyhl'adávania a kategorizácie nanotechnologických patentov, ako základ pre našu kvantitatívnu a kvalitatívnu analýzu patentovania NT v krajinách EÚ.

Interdisciplinárny charakter NT spôsobuje problémy aj pri vyhl'adávaní v patentových databázach. Pre tento typ vyhl'adávania existuje niekol'ko kl’účových stratégií, od jednoduchej stratégie vyhl'adávania predpony "nano" alebo skratky "NT", až po komplexné lexikálne a bibliometrické analýzy (Porter a kol., 2008). Existujú dva dôležité termíny na štúdium platnosti nanotechnologického patentu. Prvý z nich je tzv. prioritný termín/dátum, teda dátum, kedy je patentová prihláška podaná na patentovom úrade. Druhý je dátum zverejnenia, t.j. dátum publikovania informácií o novom patente (Sastry a kol., 2010). Prioritný dátumu umožňuje identifikovat' inovačnú výkonnost' firiem alebo univerzít. Dátum zverejnenia patentu poskytuje informácie o rýchlosti posudzovania inovácií patentovým úradom. Zemepisná pôsobnost' patentu poskytuje informácie o potenciálnom pokrytí trhu (Bonaccorsi - Thoma, 2007). A ekonomická hodnota patentu je spojená s rastom tržieb firmy, rastom trhového podielu, zvýšením hodnoty značky, ale aj s počtom a kvalitou citácií obsiahnutých v d'alších patentoch a vo vedeckej literatúre.

Patentová analýza (PA) je založené na štúdiu vydaných patentov (multi-korelácii), dížky a šírky ich platnosti, aplikačných oblastí a d'alších špecifík týchto patentov (Gallini, 2002). Hlavným ciel'om PA je identifikovat' a parciálne predvídat' trendy $\mathrm{v}$ oblasti inovácií, výrobných alebo marketingových aktivít podnikov, odvetví, regiónov a krajín, a tak lepšie plánovat' inovačné či technologické stratégie na úrovni firmy, ale aj na úrovni odvetvia, alebo regiónu, čo je aj ciel'om tejto štúdie (Grant, 2005). Referenčné údaje patentu obsahujú informácie o načasovaní vynálezu, technológii a možnej stratégii žiadatel'a (Sastry a kol., 2010). Význam patentových dát ako ukazovatel'a inovačné aktivity, sa však môže značne líšit'. Prvým dôvodom tejto nedokonalosti PA je skutočnost', že nie všetky dobré inovácie sú 
patentované. Mnoho dobrých vynálezov môže byt' ešte len v rámci revízneho procesu. Podobne, nie všetky inovácie, ktoré už boli patentované, sú tiež komerčne úspešné a často je to len malé percento, čo môže byt' problémom pre vysoko finančne náročný výskum v oblasti NT. Niekedy menšie množstvo udelených patentov prináša lepšie podnikatel'ské výsledky. Preto pre vyššiu validitu PA je vhodné kombinovat' patentové štatistiky od viacerých patentových úradov (EPO, USPTO, WIPO atd'.), alebo použit' tzv. medzinárodné patentové rodiny/skupiny, ktoré sa týkajú všetkých vydaných patentov (celosvetovo) pre konkrétne inovácie. Tento komplexnejší prístup umožňuje eliminovat' chyby a neúplnost' jednotlivých štatistík. Napríklad Bibliometrická analýza vo vzt’ahu k PA umožňujú odhadnút' životný cyklus konkrétnej inovácie presnejšie, pretože stále viac a viac patentov je citovaných aj v odbornej literatúre. V tejto parciálnej štúdii sme však využili ako základ údaje EPO, ako najkomplexnejšiu bázu dát pre informácie o patentoch $\mathrm{vEÚ}$. Ak by sme použili na porovnanie iné neúplnejšie štatistiky, presnost' údajov by sa nezlepšila.

Na zlepšenie presnosti PA môže byt' použitý aj špecifický softvér, napríklad SAS (Special analytical $S W$ ) s ciel'om ul'ahčit' štatistiku patentov a súvisiacich dát. Je vhodné tiež analyzovat' databázu WPI (World Patent Index), ktorá zahŕňa patentové dáta z viac ako 40 krajín. Táto databáza umožňuje analyzovat' kol'kokrát bola určitá patentová rodina citovaná $\mathrm{v}$ iných patentoch. Následne je vhodné určit počet vlastníkov týchto patentov, aby bolo možné identifikovat' ich technologické/inovačné činnosti. Firma ktorá vlastní najväčší počet patentov v odbore, je zvyčajne technologickým lídrom. Pre meranie komerčného úspechu inovácie je vhodné vypočítat' priemerný počet udelených patentov $\mathrm{v}$ rámci jednotlivej patentovej rodiny. ${ }^{3}$ Takto môže byt' PA dôležitým nástrojom pre lepší manažment VaV, výroby a podnikatel'skej orientácie firiem, odvetví a regiónov (Jemala, 2010). Patentové citácie sa tiež považujú za indikátor dôležitosti a rozvoja daných patentov. Citácie v dlhodobom horizonte môžu indikovat' NT, ktoré môžu byt' zameraním budúceho VaV. Početné citácie zverejnené po podaní patentovej prihlášky naznačujú nárast významu danej NT, a tak aj možnost' vzniku nového technologického odvetvia. (Bonaccorsi - Thoma, 2007) Medzinárodné patenty zaregistrované v rámci Svetovej organizácie duševného vlastníctva (WIPO), EPO a iných medzinárodných databáz by nemali byt' započítané dvakrát, aby bolo možné dosiahnut' relevantné výsledky PA.

Multidimenzionálne merítka patentového kvality NT vyžadujú aj faktorovú analýzu. Faktorové modely sa skladajú z dátových radov, ktoré možno rozdelit' do niekol'kých častí, a tak presnejšie analyzovat'. Analýza hlavných komponentov NT je cenným nástrojom pre identifikáciu kvality nanotechnologických patentov. V roku 2000 WIPO predstavila tzv. IPC (International Patent Classification) podtriedu B82B (nano-štruktúry, výroba alebo spracovanie). Ako už bolo naznačené v úvode, v tejto podtriede musí pojem NT obsahovat' aspoň jeden hlavný prvok vynálezu, ktorý je tvorený iba $\mathrm{z}$ atómu, molekuly, alebo vel'mi obmedzeného počtu atómov alebo molekúl a bol vytvorený pomocou manipulácie $\mathrm{s}$ jeho atómami alebo molekulami. Nano-štruktúry ktoré majú individuálne funkcie vzt'ahujúce sa k nano-vel'kosti, sa zarad'ujú do tejto podtriedy bez ohl'adu na spôsob ich výroby. (WIPO, 2012) Tieto štruktúry sú tiež klasifikované na základe svojich štrukturálnych a funkčných vlastností, ak tieto špecifiká sú zaujímavé. Patentové kancelárie triedia NT podl’a

\footnotetext{
${ }^{3}$ Všeobecne je možné vykonat' PA na základe:

- počtu patentových rodín,

- počtu patentových rodín, ktoré boli následne citované v odbornej literatúre,

- počtu patentových rodín usporiadaných podl'a ich vel'kosti,

- počtu medzinárodných patentových rodín,

- počtu majitel'ov patentových práv za určitú dobu. Atd'.
} 
medzinárodnej patentovej klasifikácie (IPC). Európsky patentový úrad zaviedol v minulosti pre NT kód Y01N (EC, 2004). Nový symbol pre NT B82Y bol zavedený v rámci IPC až v roku 2011. Tento symbol ul'ahčuje klasifikáciu a vyhl'adávanie $\mathrm{v}$ patentových dokumentoch. Podl'a ECLA (Európskeho klasifikačného systému), všetky NT dokumenty sú presunuté z klasifikácie Y01N do novej klasifikácie B82Y (EPO, 2012). Klasifikácia Y01N bola pozastavená. Úrady priemyselného vlastníctva $S R$ a $\check{C} R$ rovnako využívajú túto novú klasifikáciu. ${ }^{4}$

\section{Systémová analýza nanotechnologických patentov v krajinách EÚ-28}

Na účely tretej kapitoly - analytickej štúdie bolo vyhl'adávanie v rámci tohto nového kódu vykonané $\mathrm{v}$ databáze EPO, pričom sme vyhladávali, analyzovali a kategorizovali nanatechnologické patenty od roku 1940 podl'a dekád, podl'a krajín EÚ-28, na 100000 obyvatel'ov krajiny, ku 1 mld. EUR HDP, ku počtu patentových prihlášok a ku výške rizikového kapitálu krajiny. Zamerali sme sa aj na určité rozdiely v patentovaní NT a ich možné príčiny v rozvinutých a rozvíjajúcich sa krajinách EÚ.

V minulosti viac ako 60 krajín vytvorilo národné iniciatívy pre NT (Bowman, 2007). Vytvorenie národných iniciatív je dôležité pre prepojenie národných priorít, politík a programov zameraných na $\mathrm{VaV}$, technológie i priemysel a pre zvýšenie investícií do NT (Motoyama a kol., 2011). Globálny lídri v oblasti NT sa stali USA, Japonsko, Ćína a Nemecko. V roku 2006, národná podpora pre NT bola odhadovaná približne v týchto číslach: 1350 mil. USD v USA, 1000 mil. USD v Japonsku, 430 mil. USD v Číne a 320 mil. USD v Nemecku (Jia a kol., 2011; USPTO, 2014; BMI-FNI, 2007). Vo všetkých krajinách EÚ tieto výdavkami predstavovali približne 1150 mil. EUR v roku 2006 (OECD, 2009), čo je porovnatel'né s výdavkami v USA. V EÚ bolo priemerne $60 \%$ výdavkov VaV v oblasti NT financovaných z verejných zdrojov (Schellekens, 2008). Výdavky na VaV v oblasti NT sa na Slovensku v rokoch 2006-2009 pohybovali len na úrovni 2,7-3,5 mil. USD ročne (MH SR, 2013). Napríklad v ČR investovali do VaV nanotechnológií a nanomateriálov približne 75,1 mil. USD v roku 2011 (CZSO, 2011). Od roku 2000 vlády po celom svete investovali viac než 67,5 mld. USD do financovania NT (Cientifica, 2011).

V budúcnosti môžu NT zahíňat' štyri generácie produktov: aktívne a pasívne nano-štruktúry, nano-systémy a molekulárne nano-systémy (Boer a kol., 2009). Nanotechnologické patenty sa stali aj ukazovatel'om národnej technologickej kompetencie (Jia a kol., 2011). Svetový trh ovplyvnený vynálezmi v oblasti NT bol odhadovaný na úrovni 8,2 mld. EUR v roku 2006 (Bowman, 2007) a predpokladá sa, že môže dosiahnut' úroveň až $1800-2000$ mld. EUR do roku 2015 (Schmoch a Thielmann, 2012 a EC, 2015), čo môže predstavovat' približne až 15\% svetového HDP. Tento vývoj NT môže tiež viest' k vytvoreniu okolo 2 mil. nových pracovných miest po celom svete (OECD, 2009). Do roku 2020 by mala lepšia integrácia nano-vied a iných technických, ekonomických, zdravotných a environmentálnych znalostí viest’ $\mathrm{k}$ viac masovým aplikáciám NT v priemysle, medicíne a IT (Roco, 2011).

Ak by sme sa pozreli do histórie patentovania NT, potom najviac patentov bolo udelených $\mathrm{v}$ oblasti nanomateriálov, nano-IT a nano-výroby. Nanomateriály dominujú v počte patentov už od roku 1950. Rastúci počet patentov v oblasti nano-IT môže byt' zaznamenaný v rokoch 1970-1980 v súvislosti s celkovým rozvojom IT v tej dobe (Allarakhia a Walsh, 2012). Nano-

\footnotetext{
${ }^{4}$ V triede B82 sa NT používajú vo významoch: nano-vel'kost', alebo nano-rozmer a týkajú sa kontrolovaných geometrických vel'kostí pod 100 nanometrov (nm) v jednej alebo viacerých veličinách; pričom nano-štruktúra znamená objekt, ktorý má aspoň jednu funkčnú zložku v nano-vel'kosti, ktorá je fyzikálnou, chemickou, alebo biologickou vlastnost'ou a efektom, ktoré sú jednoznačne pripísané nano-rozmerom (UPVSR, 2013).
} 
výroba sa začala rozvíjat' neskôr v rokoch 1980-1990 v dôsledku rozvoja nanomateriálov a nano-zariadení. Najvyšší nárast patentovania NT začal až po roku 2000. V období 20002015 sa celkový počet nanotechnologických patentov zvýšil v priemere o $435 \%$, čo môže súvisiet' $\mathrm{s}$ globálnym rozvojom technológií a spoločnosti, ale aj $\mathrm{s}$ výraznejším vnímaním technologických, environmentálnych a ekonomických rizík v novom tisícročí. Najmenšie množstvo nanotechnologických patentov bolo udelené $\mathrm{v}$ oblasti nano-merania. Tento trend môže byt' prepojený s vyššou náročnost'ou tohto výskumu a výraznejšími t'ažkost'ami jeho komercializácie. (Tab. 1)

Tabul'ka 1: Štatistika vydaných nanotechnologických patentov podl'a údajov EPO $(1940-2015)^{5}$

\begin{tabular}{|c|c|c|c|c|c|c|c|c|c|}
\hline & B82Y5 & B82Y10 & B82Y15 & B82Y20 & B82Y25 & B82Y30 & B82Y35 & B82Y40 & \\
\hline Roky & Medicína & IT & Interakcie & Optika & Magnetizmus & Materiály & Meranie & Výroba & Suma \\
\hline-1940 & 1 & 10 & 3 & 1 & 2 & 29 & 1 & 4 & 51 \\
\hline $\begin{array}{l}1951- \\
1960 \\
\end{array}$ & 2 & 12 & 3 & 1 & 3 & 179 & 0 & 0 & 200 \\
\hline $\begin{array}{l}1961- \\
1970\end{array}$ & 2 & 102 & 12 & 3 & 82 & 630 & 1 & 29 & 861 \\
\hline $\begin{array}{c}\text { 1971- } \\
1980\end{array}$ & 138 & 441 & 268 & 15 & 118 & 939 & 1 & 170 & 2090 \\
\hline $\begin{array}{c}\text { 1981- } \\
1990\end{array}$ & 1048 & 1804 & 662 & 1044 & 206 & 2289 & 251 & 1104 & 8408 \\
\hline $\begin{array}{l}\text { 1991- } \\
2000\end{array}$ & 7014 & 7142 & 2872 & 4692 & 3100 & 7438 & 2269 & 2981 & 37508 \\
\hline $\begin{array}{l}2001- \\
2015\end{array}$ & 18046 & 49368 & 9103 & 20508 & 11419 & 60716 & 5399 & 25936 & 200495 \\
\hline Suma & 26251 & 58879 & 12923 & 26264 & 14930 & 72220 & 7922 & 30224 & 249613 \\
\hline
\end{tabular}

Zdroj: EPO (2015)

Európsky patentový úrad (EPO) registruje $\mathrm{V}$ krajinách EÚ približne 46111 nanotechnologických patentov v rokoch 1940-2015. Medzi prvé patenty s označením B82Y patril napríklad materiály a výroba filmu od firmy General electric z roku 1940, jeden z prvých predchodcov nanomateriálov. Vo všetkých oblastiach NT v EÚ dominuje Nemecko, Francúzsko, Holandsko a Vel'ká Británia. Zatial’ čo v Nemecku, Francúzsku a VB dominujú patenty na nanomateriály, v Holandsku dominujú patenty na nano-IT. Pričom v rozvinutých krajinách EÚ dominujú nano- materiály, IT, medicínske a výrobné technológie. $\mathrm{V}$ rozvíjajúcich sa krajinách EÚ dominujú tiež nanomateriály, ale na druhom mieste sú medicínske nanotechnológie a na tret'om mieste sú výrobné nanotechnológie. Aj ked' rozdiel medzi intenzitou patentovania nanotechnológií v rozvinutých a rozvíjajúcich sa krajinách EÚ je značný, zameranie výskumu je porovnatel'né. Tento fakt môže byt' podmienený určitými globalizačnými tendenciami, kedy vyspelé firmy rozširujú svoje aktivity v rozvíjajúcich sa regiónoch z dôvodov nižších nákladov, bližších trhov atd'. (Tab. 2)

\footnotetext{
${ }^{5}$ Pre presnost' daných údajov je treba zdôraznit', že množstvo patentov v oblasti NT je prepojených na iné technológie, výrobky, alebo materiály, ktoré často vyžadujú ešte d’alšie patenty. Jedna patentovaná technológia, alebo výrobok može vyžadovat' niekol'ko rôznych druhov nanotechnologických prvkov a procesov. Mnohé nanotechnologické patenty boli pripravené v rámci medzinárodnej výskumnej kooperácie. Výskumníci a organizácia (vlastník patentu), ktorá podáva žiadost’ o patent sú často z rôznych krajín. Často je vlastníkom nano-patentu aj niekol'ko organizácií z rôznych krajín. Na základe dlhodobejšieho sledovania tejto štatistiky možno tiež povedat', že štatistika je často upravovaná a doplňovaná.
} 
Tabul'ka 2: Štatistika nanotechnologických patentov v EÚ podl'a údajov EPO (1940-2015)

\begin{tabular}{|c|c|c|c|c|c|c|c|c|c|}
\hline & B82Y5 & B82Y10 & B82Y15 & B82Y20 & B82Y25 & B82Y30 & B82Y35 & B82Y40 & \\
\hline EÚ & Medicína & IT & Interakcie & Optika & Magnetizmus & Materiály & Meranie & Výroba & Suma \\
\hline Rakúsko (AT) & 23 & 227 & 29 & 12 & 9 & 195 & 12 & 162 & 669 \\
\hline Belgicko (BE) & 274 & 182 & 24 & 20 & 10 & 561 & 24 & 123 & 1218 \\
\hline Bulharsko (BG) & 2 & 2 & 1 & 1 & 0 & 6 & 4 & 0 & 16 \\
\hline Cyprus (CY) & 3 & 6 & 1 & 0 & 1 & 17 & 0 & 8 & 36 \\
\hline Chorvátsko (HR) & 2 & 0 & 0 & 0 & 1 & 2 & 0 & 2 & 7 \\
\hline ČR (CZ) & 10 & 4 & 2 & 1 & 1 & 22 & 2 & 6 & 48 \\
\hline Dánsko (DK) & 112 & 40 & 8 & 73 & 1 & 94 & 11 & 12 & 351 \\
\hline Estónsko (EE) & 2 & 0 & 2 & 1 & 0 & 5 & 2 & 1 & 13 \\
\hline Fínsko (FI) & 23 & 124 & 8 & 18 & 5 & 374 & 2 & 110 & 664 \\
\hline Francúzsko (FR) & 1905 & 1330 & 287 & 968 & 376 & 2895 & 221 & 1149 & 9131 \\
\hline SRN (DE) & 2016 & 2972 & 566 & 1443 & 784 & 6446 & 816 & 1669 & 16712 \\
\hline Grécko (GR) & 9 & 6 & 5 & 3 & 1 & 18 & 0 & 6 & 48 \\
\hline Mad'arsko (HU) & 110 & 5 & 1 & 0 & 3 & 10 & 0 & 2 & 131 \\
\hline Írsko (IE) & 120 & 28 & 9 & 19 & 5 & 65 & 2 & 18 & 266 \\
\hline Taliansko (IT) & 394 & 189 & 24 & 92 & 15 & 556 & 8 & 121 & 1399 \\
\hline Lotyšsko (LV) & 1 & 0 & 0 & 1 & 0 & 1 & 3 & 0 & 6 \\
\hline Litva (LT) & 0 & 1 & 0 & 3 & 1 & 1 & 0 & 2 & 8 \\
\hline Luxembursko (LU) & 4 & 5 & 3 & 1 & 2 & 20 & 1 & 7 & 43 \\
\hline Malta (MT) & 3 & 0 & 1 & 0 & 0 & 4 & 2 & 1 & 11 \\
\hline Holandsko (NL) & 541 & 2599 & 69 & 310 & 930 & 864 & 51 & 1143 & 6507 \\
\hline Pol'sko (PL) & 6 & 4 & 4 & 11 & 0 & 56 & 4 & 12 & 97 \\
\hline Portugalsko (PT) & 6 & 1 & 1 & 4 & 0 & 16 & 0 & 6 & 34 \\
\hline Rumunsko (RO) & 1 & 5 & 2 & 3 & 4 & 8 & 0 & 6 & 29 \\
\hline Slovensko (SK) & 1 & 0 & 0 & 0 & 0 & 6 & 2 & 1 & 10 \\
\hline Slovinsko (SI) & 9 & 2 & 1 & 1 & 2 & 16 & 0 & 1 & 32 \\
\hline Španielsko (ES) & 228 & 55 & 24 & 23 & 15 & 413 & 41 & 108 & 907 \\
\hline Švédsko (SE) & 225 & 465 & 64 & 157 & 37 & 495 & 16 & 258 & 1717 \\
\hline VB (GB) & 974 & 1008 & 304 & 894 & 152 & 1834 & 222 & 613 & 6001 \\
\hline Suma & 7004 & 9260 & 1440 & 4059 & 2355 & 15000 & 1446 & 5547 & 46111 \\
\hline USA (US) & 1190 & 528 & 595 & 398 & 93 & 2663 & 86 & 1882 & 7435 \\
\hline Čína $(\mathrm{CN})$ & 67 & 30 & 41 & 51 & 7 & 322 & 5 & 295 & 818 \\
\hline Japonsko (JP) & 129 & 587 & 129 & 672 & 54 & 1678 & 52 & 1065 & 4366 \\
\hline
\end{tabular}

Zdroj: EPO (2015)

Najmenej patentované NT v EÚ-28 sú nano-merania, nano-magnetizmus a nano-interakcie. V krajinách EÚ sú nižšie výskumné kapacity a záujem o tieto oblasti. Krajiny ktoré majú najmenší počet nanotechnologických patentov sú Chorvátsko, Lotyšsko a Litva. Celkovo je evidovaných v databáze EPO približne 10 nanotechnologických patentov pre SR a 48 nanopatentov pre ČR. V priemere je evidovaných 3259 NT patentov vo vyspelých krajinách a len 35 patentov v rozvíjajúcich sa krajinách EÚ. Európske patenty, ktoré spadajú pod Zmluvu o patentovej spolupráci sú však vel'mi kvalitné (Bonaccorsi a Thoma, 2007). Z hl'adiska dynamiky rastu nanotechnologických patentov patrí prvé miesto Francúzku, kde až 16 univerzitných inštitúcií poskytuje vzdelávanie a zabezpečuje výskum $\mathrm{v}$ oblasti NT. V súkromnom sektore je evidovaných približne 40 firiem so zameraním na nano-vedu a nanotechnológie. (Nanowerk, 2015) Ak by sme sa pozreli aj na porovnanie krajín EÚ $\mathrm{s}$ USA, Ćínou a Japonskom $\mathrm{v}$ rámci špecializácie výskumu $\mathrm{v}$ oblasti NT, tak v týchto krajinách rovnako dominujú nano-materiály, na druhom mieste je však nano-výroba a na tret'om mieste sú rovnako medicínske nanotechnológie

Ak sa pozrieme na počet nanotechnologických patentov na 100000 obyvatel'ov, tak na prvé miesto patrí Holandsko s 39,1 patentmi. Druhé miesto patrí Nemecku a tretie Švédsku, s 20,4 a 18,5 patentmi na 100000 obyvatel'ov. Všetky tieto krajiny sú považované za rozvinuté ekonomiky. Zatial' čo v rozvíjajúcich sa ekonomikách, ako sú Lotyšsko, Litva, Malta a aj Slovensko je to len 0,2 patentu na 100000 obyvatel'ov. V priemere je to 6,2 NT patentov 
na 100000 obyvatel’ov v krajinách EÚ, pričom vo vyspelých krajinách je to 11,5 patentov v priemere a v rozvíjajúcich sa krajinách EÚ, je to len 0,96 patentu na 100000 obyvatel'ov. Celkovo 11 rozvinutých ekonomík EÚ (AT, BE, DK, FI, FR, DE, IE, LU, NL, SE, GB) dosahuje nadpriemerné výsledky pri tomto ukazovateli. Menej priaznivé výsledky dosahujú vyspelé ekonomiky, ako sú Taliansko, Španielsko a Portugalsko. Z týchto krajín hlavne Portugalsko má menší počet nanotechnologických patentov evidovaných v rámci EPO. Hoci $\mathrm{v}$ menšom Portugalsku sú tri univerzitné inštitúcie so zameraním na nanotechnológie (Laboratório Ibérico Internacional de Nanotechnologia; Universidade da Madeira; Universidade de Aveiro), ktoré poskytujú aj vzdelávanie v danej oblasti. Dôvodom môže byt', že vel'a výskumných inštitúcií v Portugalsku spolupracuje so španielskymi výskumnými inštitúciami, ktoré intenzívnejšie patentujú nanotechnológie. Toto je časté v mnohých rozvíjajúcich sa ekonomikách EÚ, ktoré zabezpečujú určitý výskum v oblasti NT, ale patentovanie NT a ich komercializácia sa realizuje medzinárodnými firmami, ktoré na to majú lepšie predpoklady a kapacity. (Obr. 1$)$

Obrázok 1: Počet nanotechnologických patentov v EÚ na 100000 obyvatel’ov (1940-2015)

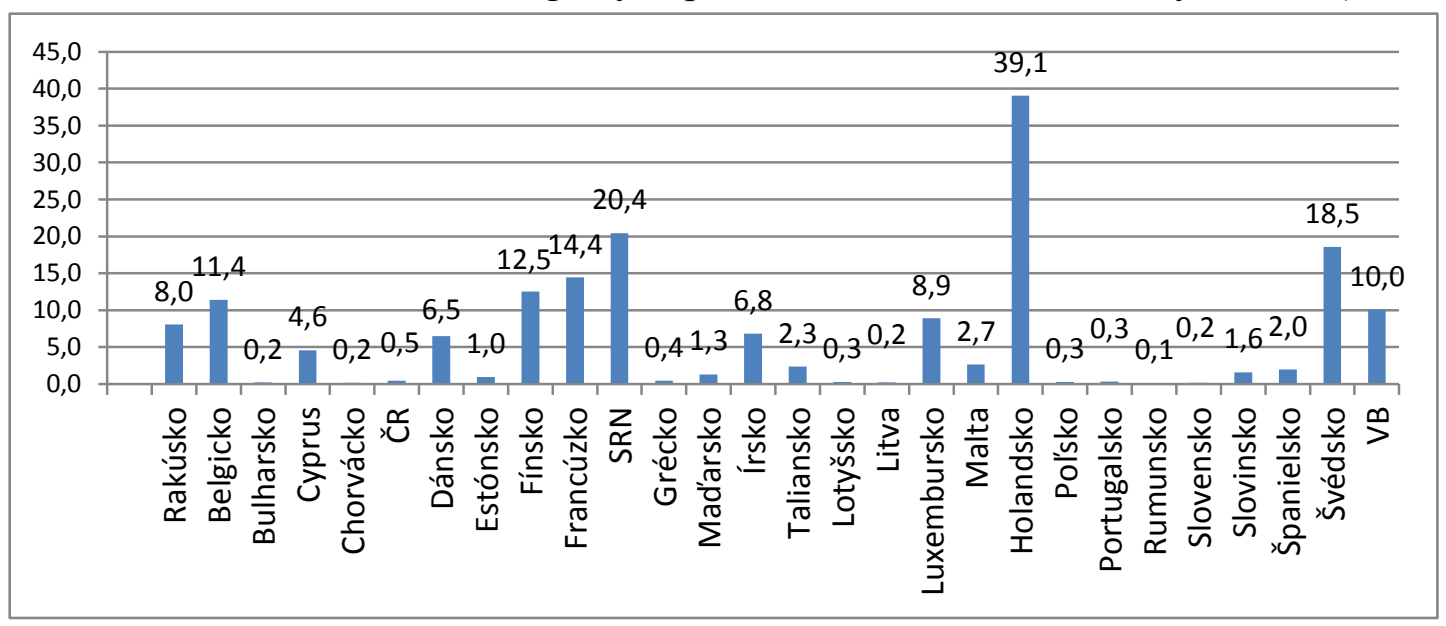

Zdroj: EPO (2015), UN (2014b)

Ak porovnáme počet nanotechnologických patentov ku výkonu národnej ekonomiky, napr. ku 1 mld. EUR národného HDP, tak opät prvé miesto patrí Holandsku s 10,82 patentmi. Druhé miesto patrí Nemecku a tretie Švédsku, s 6,45 a 4,72 patentmi ku 1 mld. EUR národného HDP. Zatial' čo v rozvíjajúcich sa ekonomikách, ako sú Slovensko a Chorvátsko, ale aj v Portugalsku, je to len 0,15-0,2 patentu ku 1 mld. EUR národného HDP. V priemere v krajinách EÚ je to 1,96 patentu ku 1 mld. EUR HDP. V rozvinutých krajinách EÚ je to 3,25 patentu v priemere, a v rozvíjajúcich sa krajinách EÚ je to len 0,67 patentu ku 1 mld. EUR HDP. Nadpriemerné výsledky boli dosiahnuté 8 (rovnakými) vyspelými krajinami EÚ (AT, BE, FI, FR, DE, SE, UK, NL), ako pri predchádzajúcom ukazovateli, ale aj napríklad na Cypre. Cyprus má len malé množstvo výskumných organizácií zaoberajúcich sa výskumom v oblasti NT (napr. Nanogen, alebo Rosseter Holdings Limited), ale až 4 univerzity sa zaoberajú výskumom a vzdelávaním v oblasti NT (Cyprus University of Technology; University of Cyprus; Cyprus International University a Frederick University). Nanotechnologický výskum na Cypre je značne ovplyvnený aj negatívnymi dôsledkami finančnej krízy na Cypre. Rast HDP na roky 2015-2016 je odhadovaný len vo výške 0,61,1\% (Economist, 2015). Celkovo však možno zhrnút', že vyspelé krajiny EÚ s vyšším HDP podporujú viac $\mathrm{VaV}$ a patentovanie NT a majú lepšie synergické kapacity na riešenie rôznych krízových situácií. Zároveň tieto krízové finančné stavy nemusia tak negatívne vplývat' 
na financovanie výskumu $\mathrm{v}$ oblasti NT, a to aj $\mathrm{z}$ dôvodu širších možností získavania finančných prostriedkov. (Obr. 2)

Obrázok 2: Počet nanotechnologických patentov v EÚ ku 1 mld. EUR HDP (1940-2015)

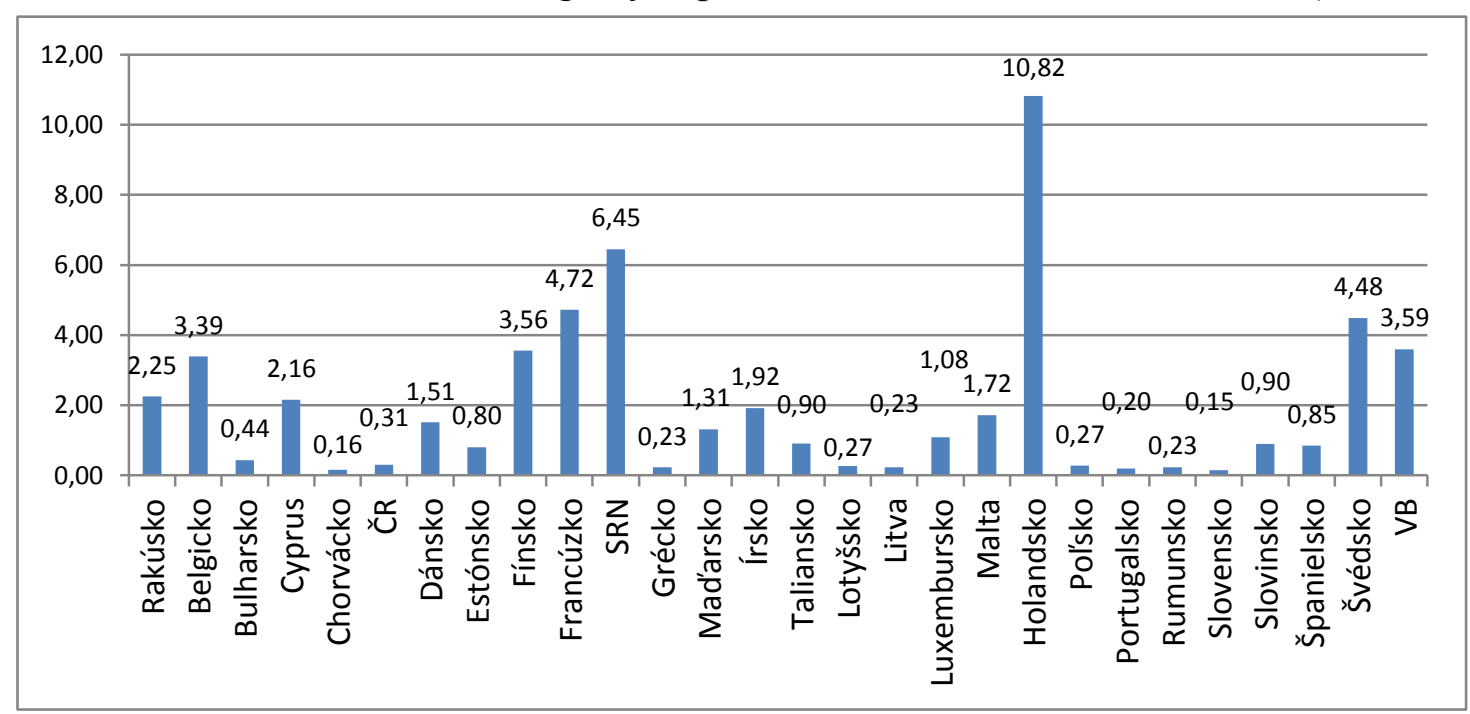

Zdroj: EPO (2015), UN (2014a)

Ak by sme sa pozreli na priemernú úspešnost' patentových prihlášok, potom najúspešnejšími krajinami EÚ z hl'adiska udelených patentov v oblasti NT v porovnaní s patentovými prihláškami sú vyspelé ekonomiky: Belgicko, Írsko, SRN a Francúzsko. ${ }^{6}$ V týchto krajinách je úspešných viac ako $75 \%$ patentových prihlášok. Aj ked' z hl'adiska celkového počtu udelených nanotechnologických patentov patrí Írsko medzi krajiny s pomerne nízkym počtom patentov. Francúzsko, SRN a Belgicko patria medzi vyspelé ekonomiky s väčším počtom udelených nanotechnologických patentov. Medzi najmenej úspešné krajiny EÚ, pokial' ide o patentové prihlášky v rámci EPO patria Lotyšsko, ČR a Slovinsko, aj ked' nebolo možné získat' presné informácie zo všetkých krajín EÚ-28. Na Slovensku je úspešných približne $31 \%$ patentových prihlášok. Podl'a tohto kritéria môžeme tiež konštatovat', že krajiny EÚ, ktoré majú vyšší počet udelených nanotechnologických patentov sú zvyčajne úspešnejšie/efektívnejšie z hl'adiska patentového konania. Toto môže byt' podmienené dlhšou skúsenost'ou, lepšou prípravou a celkovou vyššou profesionalitou pri podávaní patentových prihlášok. Priemerná miera úspešnosti tohto konania v EÚ je $46 \%$, zatial' čo v rozvinutých ekonomikách je to $56 \%$, a $\mathrm{v}$ rozvíjajúcich sa ekonomikách je to $\mathrm{v}$ priemere $34 \%$. Nadpriemerné výsledky boli dosiahnuté v 9 krajinách EÚ pri tomto ukazovateli (BE, FI, DE, GR, HU, IE, LU, ES, SE). Spomedzi rozvíjajúcich sa krajín EÚ nadpriemerné výsledky dosiahlo Grécko a Mad'arsko. Grécko má pomerne malé množstvo registrovaných patentov v rámci EPO (len 48) aj oproti Mad'arsku (141), aj ked' v krajine existuje niekol'ko podporných organizácií v oblasti NT (Nano|net; National Hellenic Research Foundation; alebo Micro\&Nano Scientific Society). Všetky tieto iniciatívy sú zamerané na podporu komunikácie, financovania a spolupráce $\mathrm{v}$ oblasti NT. Najznámejšie výskumné centrá v Grécku v oblasti NT sú na Aristotle University of Thessaloniki; Institute of Microelectronics; alebo Laboratory of High Tech Materials. V rámci negatívnej finančnej situácie Grécka sú mnohé výskumné aktivity aj v oblasti NT rušené a mnohí výskumníci odchádzajú za prácou do zahraničných krajín (Trachana, 2013). Jedna z hlavných súkromných organizácií, ktorá podporuje výskum a výrobu $\mathrm{v}$ oblasti NT $\mathrm{v}$ Mad'arsku sa nazýva NANOBAKT Ltd. Medzi hlavné výskumné inštitúcie v oblasti NT v krajine patria Hungarian

\footnotetext{
${ }^{6}$ Nebolo možné zistit' presné údaje vo Francúzsku pri tomto ukazovatel’ovi.
} 
Academy of Sciences; University of Szeged; alebo University of Pannonia. Napriek podobným finančným problémom Mad'arska v poslednej dobe sa darí znižovat' verejný dlh krajiny, a tak ostáva aj viac prostriedkov na financovanie výskumu v oblasti NT. Celkovo stále však existujú vel'mi obmedzené prostriedky (najmä pokial' ide o rizikový kapitál), ako aj infraštruktúru na podporu VaV v oblasti NT. (Obr. 3)

Obrázok 3: Pomer priemernej úspešnosti nanotechnologických patentov v EÚ ku patentovým prihláškam EPO (1940-2015)

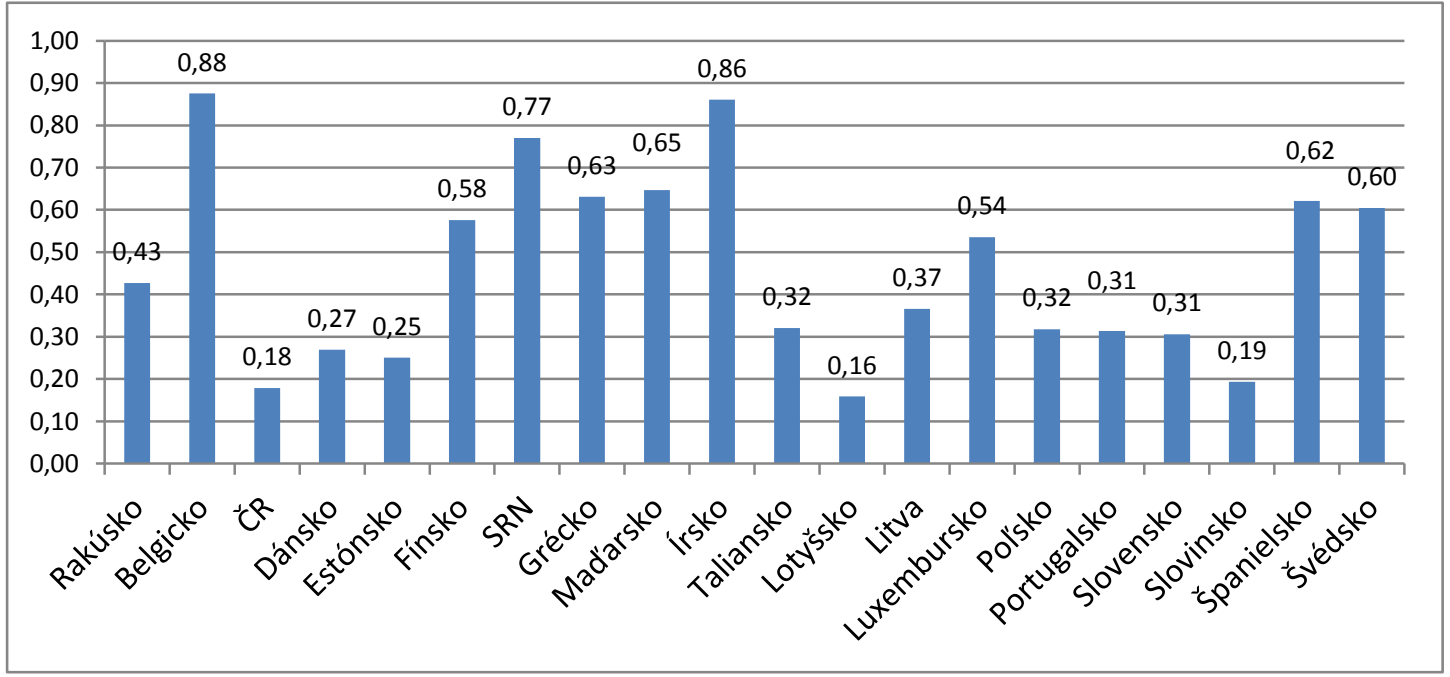

Zdroj: EPO (2015), OECD (2014)

Zvýšenie investícií do NT $\mathrm{v}$ hlavne rozvíjajúcich sa krajinách EÚ pomôže zvýšit' počet patentových prihlášok v rámci národných patentových úradov, ale aj EPO (Scheu a kol., 2006). Je tu aj otázka efektívnosti a návratnosti vložených investícií. Investície do NT sú často viac rizikové, pokial' ide o dotiahnutie výskumu do komerčných produktov, technológií a služieb. Preto takéto investície vyžadujú primeraný podnikatel'ský plán a určitú diverzifikáciu rizík spojených s výskumom a jeho komercializáciou. Rizikový kapitál (RK) je jedna možnost' tejto diverzifikácie, ale je tiež dôležitý pre rozvoj menších inovatívnych fíriem a projektov v oblasti NT. Rizikový kapitál je však finančne drahší ako bežný podnikatel'ský úver, preto často vyžaduje vyššiu návratnost' vložených prostriedkov, čo môže znamenat' pre nejasný výskumný projekt d’alšie riziko. V súvislosti so zlepšovaním globálneho ekonomického prostredia, rok 2013 bol považovaný za zlomový rok pre európsky trh RK. Hodnota investícií do RK vzrástla o $19 \%$ na 7,4 mld. USD. Napríklad v tom istom roku investície do RK v Č́ne klesli o $30 \%$ na hodnotu 3,5 mld. USD. (EY, 2014) Podl'a údajov z roku 2014, najväčší podiel rizikového RK na národnom HDP malo Fínsko, Írsko a Švédsko. Všetky tieto krajiny možno považovat' za nadpriemerných inovátorov v oblasti NT podl'a tejto štúdie. Najmenší podiel rizikového kapitálu (RK) na národnom HDP mal Cyprus, Chorvátsko, ČR, Lotyšsko, Litva, Malta, Slovensko a Slovinsko. Tieto krajiny možno považovat' za rozvíjajúce sa, aj pokial' ide o finančný sektor. V priemere v krajinách EÚ investície RK by mali tvorit' 3,5 \% HDP (Beaudry a Allaoui, 2012). Podl'a našich údajov je to v priemere len $1,7 \%$, čo je porovnatel'né s USA. Pričom v rozvinutých ekonomikách EÚ je to okolo 3,1\% HDP a 0,3\% HDP v rozvíjajúcich sa ekonomikách EÚ. Na základe tejto analýzy nie je možné uviest', že vyšší podiel RK na národnom HDP prináša aj väčšie množstvo nanotechnologických patentov. Napríklad vo Fínsku podiel investícií do RK na HDP je podstatne väčší (6,7 \% HDP) ako v Holandsku (3,2 \% HDP), napriek tomu Holandsko eviduje podstatne viac nanotechnologických patentov. Môžeme však identifikovat', že vo Francúzsku, 
SRN, Holandsku a VB, väčší podiel týchto investícií znamená aj viac patentov v oblasti NT. (Obr. - 4)

Obrázok 4: Štatistika nanotechnologických patentov v EÚ (1940-2015) verzus investície rizikového kapitálu ako \% z HDP

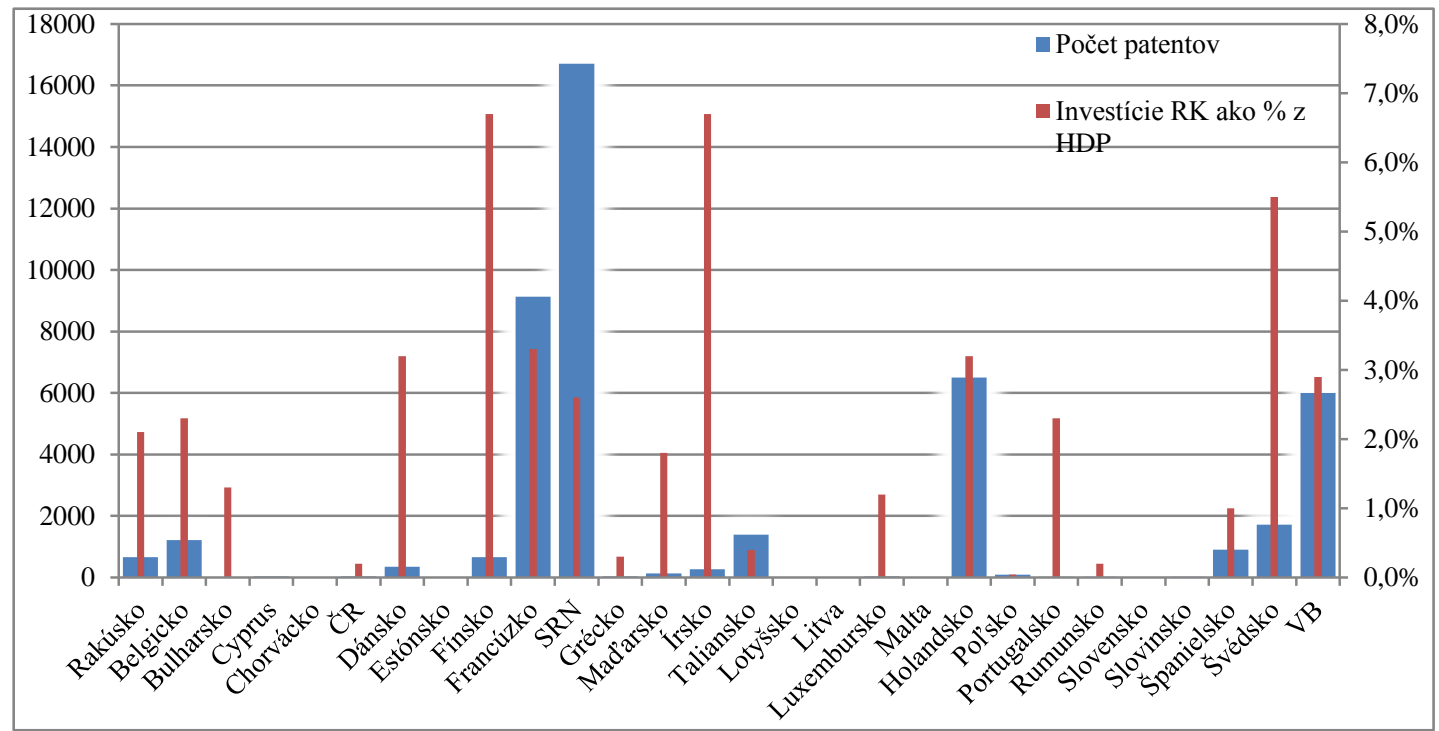

Zdroj: EPO (2015), OECD (2014), EC (2013)

Rizikový kapitál je však v prvom rade určený na rizikové projekty, nielen v oblasti NT. Nanotechnologické podniky/projekty často potrebujú využit' kombináciu vlastných a cudzích zdrojov pre financovanie vlastných inovácií, vstupovat' do podnikatel'ských aliancii/klastrov a nových hodnotových sietí (Mangematin a Walsh, 2012). Práve vedecko-výskumné siete v oblasti NT sú špecifické vysokým stupňom rozmanitosti/unikátnosti spolupráce (Raesfeld a kol., 2012), ale aj významnou úlohou RK. Je však potrebné vytvorit' určitý jednotný mechanizmus pre poskytovanie RK pre rôzne druhy podnikatel'ských subjektov. Zároveň je potrebná určitá synergická kooperácia všetkých účastníkov VaV v oblasti NT, aby sa predišlo duplicitám a neefektívnosti pri patentovaní a komercializácií týchto inovácií. Problematika financovania $\mathrm{VaV}$ v oblasti NT a účinnosti vstupovania menších inovatívnych podnikov do aliancii a klastrov pre rozvoj NT je však už témou pre d'alší výskum.

\section{Záver}

Určité základy nanotechnologickej disciplíny možno nájst' už v roku 1870, ked' dvaja profesori Elihu Thomson a Edwin Houston experimentovali a neskôr patentovali vynálezy na existujúce oblúkové lampy a dizajn dynama. Špecifický materiál i proces uhlíkovej oblúkovej lampy bol prvý typ elektrického svetla a prvá komerčne úspešná konštrukcia elektrickej lampy. Medzi prvé oblasti patentovania NT patrili: nanomateriály, nano-výroba a nanointerakcie. Nanomateriály stále patria medzi najviac patentované NT. Do súčasnosti viac ako 60 krajín vytvorilo národné iniciatívy pre rozvoj NT. Vytvorenie národných iniciatív bolo dôležité pre prepojenie národných priorít, politík a programov zameraných na $\mathrm{VaV}$, technológie i priemysel a pre zvýšenie investícií do NT (Nikulainen a Palmberg, 2010). NT priniesli nové kvality materiálov, nové technológie $\mathrm{v}$ zdravotníctve vo vel'kosti buniek, nové možnosti pre výskum voblasti recyklácie odpadov a emisií, zlepšenia vlastností priemyselných výrobkov, až po mnohé inovácie pre produkty bežnej spotreby. Tieto inovácie však priniesli aj mnohé riziká možných neočakávaných problémov pri používaní nanotechnológií, čo vedie $\mathrm{k}$ vyšším výdavkom na komplexné technologické hodnotenie a predchádzanie rizík z používania týchto materiálov, výrobkov a technológií. 
Globálny lídri v oblasti NT sa stali najvyspelejšie ekonomiky: USA, Japonsko, Čína a Nemecko. Svetový trh ovplyvnený vynálezmi v oblasti NT bol odhadovaný na úrovni 8,2 mld. EUR v roku 2006 (Bowman, 2007) a predpokladá sa, že môže dosiahnut' úroveň až 2000 mld. EUR do konca roku 2015 (Schmoch a Thielmann, 2012; EC, 2015), čo môže predstavovat' približne až $15 \%$ svetového HDP. Len v rokoch 2000-2011 vlády po celom svete investovali viac ako 67,5 mld. USD do financovania NT (Cientifica, 2011). V období 2000-2015 sa celkový počet nanotechnologických patentov zvýšil v priemere o $435 \%$, čo môže súvisiet' $s$ globálnym rozvojom technológií a spoločnosti, ale aj $\mathrm{s}$ výraznejším vnímaním technologických, environmentálnych a ekonomických rizík v novom tisícročí.

Vo všetkých oblastiach inovácií NT v EÚ dominujú tiež najvyspelejšie ekonomiky EÚ: Nemecko, Francúzsko, Holandsko a Vel'ká Británia. Pričom v rozvinutých krajinách EÚ dominujú nano- materiály, IT, medicínske a výrobné technológie. V rozvíjajúcich sa krajinách EÚ dominujú tiež nanomateriály, ale na druhom mieste sú medicínske nanotechnológie a na tret’om mieste sú tiež výrobné nanotechnológie. Najmenej patentované NT v EÚ-28 sú nano-merania, nano-magnetizmus a nano-interakcie. V krajinách EÚ sú nižšie výskumné kapacity a záujem o tieto oblasti, čo môže súvisiet' s historickou orientáciou vzdelávania a $\mathrm{VaV}$, ale aj s menšou možnost'ou komercializácie tohto výskumu. Z hl'adiska prepojenia zamerania vzdelávania/výskumu/podnikatel'ského sektora je možné identifikovat' hlavne v rozvíjajúcich sa ekonomikách EÚ určité disproporcie, čo môže viest' k nižšej efektívnosti a výsledkom výskumu aj v oblasti NT (Iyuke a kol., 2007). Z tohto dôvodu je potrebné začat' s podporou NT už na univerzitách a vytvárat' účinné prepojenia výskumu s podnikatel'skou praxou a reálnymi požiadavkami príslušných trhov a regiónov.

Ak sa pozrieme na počet nanotechnologických patentov na 100000 obyvatel'ov, tak na prvé miesto patrí Holandsko s 39,1 patentmi. Druhé miesto patrí Nemecku a tretie Švédsku; s 20,4 a 18,5 patentmi na 100000 obyvatel'ov. Ak porovnáme počet nanotechnologických patentov ku výkonu národnej ekonomiky, t.j. ku 1 mld. EUR národného HDP, tak opät' prvé miesto patrí Holandsku s 10,82 patentmi. Druhé miesto patrí opät' Nemecku a tretie Švédsku; s 6,45 a 4,72 patentmi ku 1 mld. EUR národného HDP. Všetky tieto krajiny sú považované za rozvinuté ekonomiky pokial ide o ekonomický a technologický rozvoj, ale aj určité sociálno-environmentálne povedomie o výhodách i rizikách technologického rozvoja. Tieto aspekty sú často podceňované $\mathrm{v}$ rozvíjajúcich sa ekonomikách EÚ, čo môže prinášat' d'alšie riziká pre dané regióny i verejnú podporu v oblasti NT. Celkovo však možno zhrnút', že vyspelé krajiny EÚ s vyšším HDP podporujú viac $\mathrm{VaV}$ a patentovanie NT a majú aj lepšie synergické kapacity na riešenie rôznych krízových situácií. Zároveň tieto krízové stavy nemusia tak negatívne vplývat' na financovanie a podporu výskumu v oblasti NT z dôvodu širších možností získavania finančných prostriedkov a diverzifikácie súvisiacich rizík.

Ak by sme sa pozreli na úspešnost' patentových prihlášok, potom najúspešnejšími krajinami v EÚ z hl'adiska udelených patentov v oblasti NT v porovnaní s patentovými prihláškami sú opät' vyspelé ekonomiky: Belgicko, Írsko, SRN a Francúzsko. Podl'a tohto kritéria môžeme konštatovat', že vyspelé krajiny EÚ, ktoré majú vyšší počet udelených nanotechnologických patentov sú zvyčajne úspešnejšie/efektívnejšie z hl'adiska patentového konania. Toto môže byt' podmienené dlhšou skúsenost'ou, lepšou prípravou a celkovou vyššou profesionalitou pri podávaní patentových prihlášok. Dôvodom môže byt' aj, že vel'a výskumných inštitúcií v rozvíjajúcich sa ekonomikách EÚ zabezpečuje čast' výskumu v oblasti NT, ale patentovanie NT a ich komercializácia sa realizuje zahraničnými firmami, ktoré na to majú lepšie predpoklady a kapacity. Treba však povedat', že tieto firmy, často viac "riskujú" v oblastiach, kde sú menej prísne právne predpisy, ale aj nižšie súvisiace náklady. 
Pokial ide o financovanie $\mathrm{VaV}$ spojeného s NT, vyspelejšie ekonomiky využívajú viac kombináciu finančných nástrojov pre rozloženie rizík, hlavne sa intenzívnejšie uchádzajú o fondy/prostriedky EÚ, ale aj o rizikový kapitál, pokial' je jasné, že bude možné úspešne komercializovat' dané inovácie. Podl'a údajov z roku 2014, najväčší podiel rizikového RK na národnom HDP malo Fínsko, Írsko a Švédsko. Všetky tieto krajiny možno považovat' za nadpriemerných inovátorov v oblasti NT podl'a tejto štúdie. Z hladiska lepšieho využitia RK aj $\mathrm{v}$ menej rozvinutých regiónoch EÚ je však potrebné vytvorit' určitý jednotný mechanizmus pre poskytovanie RK pre rôzne druhy podnikatel'ských subjektov. Zároveň je potrebná určitá synergická kooperácia menších a väčších účastníkov VaV v oblasti NT v EÚ, aby sa predišlo duplicitám a neefektívnosti pri patentovaní a komercializácií týchto inovácií. Patentovanie NT v EÚ je stále značne administratívne, časovo i finančne náročná aktivita hlavne pre MSP. Pre konkurencieschopnost' európskych patentov je však potrebné zlepšovat' a zrýchl'ovat' patentové konanie, odstraňovat' patentové bariéry a prekrývajúce sa práva. A stále viac a viac sa objavujú požiadavky aj na globálny patentový systém, ktorý by umožnil znížit' náklady na patentovú ochranu pre vynálezcu i právneho nástupcu, zjednodušit' a zjednotit' patentovú ochranu v oblasti NT. Na prvom mieste aj pri tomto druhu výskumu však musí zostat' zdravie l’udí a trvalá socio-enviromentálna udržatel'nost' prostredia.

\section{Literatúra:}

[1] ALLARAKHIA, M. a S. WALSH, 2012. Analyzing and organizing NT development: Application of the institutional analysis development framework to NT consortia. Technovation, 32(3-4), 216-226. ISSN 0166-4972.

[2] BEAUDRY, C. a S. ALLAOUI, 2012. Impact of public and private research funding on scientific production: The case of NT. Research Policy, 41(9), 1589-1606. ISSN 00487333.

[3] BEAUDRY, C. a A. SCHIFFAUEROVA, 2011. Impact of collaboration and network indicators on patent quality: The case of Canadian NT innovation. European Management Journal, 29(5), 362-376. ISSN 0263-2373.

[4] BEESEN, J., 2003. Patent Thickets: Strategic Patenting of Complex Technologies, Research on Innovation. Boston University School of Law [on-line]. [cit. 2. 2. 2015]. Dostupné z: http://www.researchoninnovation.org/thicket.pdf

[5] BMI-FNI, 2007. Productive Nanosystems: A Technology Roadmap, Battelle Memorial Institute and Foresight Nanotech Institute, United States Government manuscript, No.DE-AC05-00OR22725.

[6] BOER, D., A. RIP a S. SPELLER, 2009. Scripting possible futures of nanotechnologies: A methodology that enhances reflexivity. Technology in Society, 31(3), 295-304. ISSN 0160-791X.

[7] BONACCORSI, A. a G. THOMA, 2007. Institutional complementarity and inventive performance in nano science and technology. Research policy, 36(6), 813-831. ISSN 0048-7333.

[8] BOWMAN, D. M., 2007. Patently obvious: Intellectual property rights and NT. Technology in Society, 29(3), 307-315. ISSN 0160-791X.

[9] CHAMAS, I. C., 2008. NT intellectual property in Brazil: Preliminary research note. World patent information, 30(2), 146-149. ISSN 0172-2190.

[10] CALTECH, 2015. The Feynman Lectures on Physics, Caltech. Caltech [on-line]. [cit 3. 5. 2015]. Dostupné z: http://www.feynmanlectures.caltech.edu/ 
[11] CIENTIFICA, 2011. Global Nanotechnology Funding 2011. Cientifica [on-line]. [cit 7. 2. 2014]. Dostupné z: http://www.cientifica.com/research/white-papers/globalnanotechnology-funding-2011/

[12] CZSO, 2011. Výdaje na VaV ve vybraných oblastech v roce 2011. CZSO [on-line]. [cit 10. 2. 2015]. Dostupné z: http://www.czso.cz/csu/ 2012edicniplan.nsf/t/E9002B07F0/\$File/96011258.pdf.

[13] DREXLER, E. K., 1996. Engines of Creation. London: Fourth Estate. ISBN 9781857024869.

[14] EC, 2004. Towards European strategy for NT. EC [on-line]. [cit 15. 3. 2013]. Dostupné z: http://ec.europa.eu/NT/pdf/nano_com_en.pdf

[15] EC, 2013. Total venture capital investment \% of GDP. EC [on-line]. [cit 2. 3. 2015]. Dostupné $\quad \mathrm{z}$ : $\mathrm{http} / / / \mathrm{ec}$.europa.eu/enterprise/policies/finance/data/enterprise-financeindex/venture-capital/index_en.htm

[16] EC, 2015. Policy issues. EC [on-line]. [cit 7. 3. 2015]. Dostupné z: http://ec.europa.eu/research/industrial_technologies/policy_en.html

[17] ECONOMIST, 2015. Cyprus: In brief. The Economist [on-line]. [cit 3. 3. 2015]. Dostupné z: http://country.eiu.com/cyprus

[18] EPO, 2012. NT - A special tagging system. European patent office [on-line]. [cit 15. 3. 2012]. Dostupné z: http://www.epo.org/news-issues/issues/classification/NT.html

[19] EPO, 2015. Advanced search. European Patent Office [on-line]. [cit 17. 2. 2015]. Dostupné z: http://worldwide.espacenet.com/advancedSearch?DB=EPODOC\&submitted $=$ false $\&$ locale $=$ en_EP $\& A B=\& S T=$ advanced $\&$ compact $=$ false

[20] EY, 2014. Adapting and evolving Global venture capital insights and trends 2014. Ernst Young [on-line]. [cit 10. 2. 2015]. Dostupné z: http://www.ey.com/ Publication/vwLUAssets/Global_venture_capital_insights_and_trends_2014/\$FILE/EY_ Global_VC_insights_and_trends_report_2014.pdf

[21] FIEDLER, M. a I. M. WELPE, 2010. Antecedents of cooperative commercialization strategies of NT firms. Research policy, 39(3), 400-410. ISSN 0048-7333.

[22] GALLINI, N. T., 2002. The Economics of Patents: Lessons from Recent U.S. Patent Reform. Journal of Economic Perspectives, 16(2), 131-54. ISSN 0895-3309.

[23] GIACHETTI, C. a G. MARCHI, 2010. Evolution of firms product strategy over the life cycle of technology-based industries: A case study of the global mobile phone industry, 1980-2009. Business History, 52(7), 1123-1150. ISSN 0007-6791.

[24] GRANT, R. M., 2005. Contemporary strategy analysis. Malden: Blackwell Publishing, 5th edition. ISBN 1-4051-1999-3.

[25] HICKS, J. B., G. GRISSETT a B. A. BROWN, 2010. Is there really plenty of room at the bottom? Womble Carlyle Sandridge \& Rice. PLLC [on-line]. [cit 22. 3. 2015]. Dostupné z: http://www.wcsr.com/resources/pdfs/nano030310.pdf

[26] HOLME, M., 2013. Differences between US and European patent applications. WIPR [on-line]. [cit 25. 3. 2015]. Dostupné z: http://www.worldipreview.com/ article/differences-between-us-and-european-patent-applications

[27] IPO.GOV, 2013. EPO Utilisation Scheme. IPO.GOV.UK [on-line]. [cit 17. 3. 2015]. Dostupné z: http://www.ipo.gov.uk/pro-types/pro-patent/p-policy/p-policy-backlog/ppolicy-worksharing/p-policy-utilisation.htm 
[28] IYUKE, P. O., M. CROSS, S. E. IYUKE a H. J. POTGIETER, 2007. The Role of a University in Education and Training in the Field of NT, The Case of the University of the Witwatersrand. Education for Chemical Engineers, 2(1), 56-67. ISSN 1749-7728.

[29] JEMALA, L., 2010. Innovation of Leadership and Management. Forum Statisticum Slovacum, VII(4), 45-51. ISSN 1336-7420.

[30] JEMALA, M., 2010. Evolution of Foresight in the Global Historical Context. Foresight, 12(4), 65-81. ISSN 1463-6689.

[31] JEMALA, M., 2012. Nature of Foresight Planning. LAP Saarbrücken: LAMBERT Academic Publishing. ISBN 978-3659131509.

[32] JEMALA, M., 2013. On global sustainability and regional environmentally oriented foresights. Int. J. Agile Systems and Management, 6(2), 118-140. ISSN 1741-9174.

[33] JAIN, A., S. HALLIHOSUR a L. RANGAN, 2011. Dynamics of NT Patenting: An Indian Scenario. Technology in Society, 33(1), 137-144. ISSN 0160-791X.

[34] JIA, L., Y. ZHAO a X. J. LIANG, 2011. Fast evolving NT and relevant programs and entities in China. Nano Today, 6(1), 6-11. ISSN 1748-0132.

[35] JRC, 2013. Nanomaterials Repository. JRC [on-line]. [cit 25. 3. 2013]. Dostupné z: http://ihcp.jrc.ec.europa.eu/our_activities/NT/nanomaterials-repository

[36] MANGEMATIN, V. a S. WALSH, 2012. The future of nanotechnologies. Technovation, 32(3-4), 157-160. ISSN 0166-4972.

[37] MH SR, 2013. Inovačná politika na roky 2011-2013 v pôsobnosti Ministerstva hospodárstva SR. MH SR [on-line]. [cit 14. 11. 2014]. Dostupné z: www.economy.gov.sk/index/open_file.php?ext_dok=136692

[38] MOTOYAMA, Y., R. APPELBAUM, a R. PARKER, 2011. The National NT Initiative: Federal support for science and technology, or hidden industrial policy? Technology in Society, 33(1-2), 109-118. ISSN 0160-791X.

[39] NANOWERK, 2015. Nanotechnology in France - companies, research, and degree programs. Nanowerk [on-line]. [cit 21. 2. 2015]. Dostupné z: http://www.nanowerk.com/nanotechnology/Nanotechnology_Companies_Research_and_ Degree_Programs_in_France.php

[40] NIKULAINEN, T. a CH. PALMBERG, 2010. Transferring science-based technologies to industry - Does NT make difference? Technovation, 30(1), 3-11. ISSN 0166-4972.

[41] OECD, 2009. NT: An Overview Based on Indicators and Statistics. OECD [on-line]. [cit 15. 5. 2014]. Dostupné z: http://www.oecd.org/sti/inno/43179651.pdf

[42] OECD, 2014. OECD Science, Technology and Industry Scoreboard 2014. OECD [online]. [cit 17. 3. 2015]. Dostupné z: http://www.oecd.org/sti/oecd-science-technologyand-industry-outlook-19991428.htm

[43] PORTER, A. L., J. YOUTIE, P. SHAPIRA a D. J. SCHOENECK, 2008. Refining search terms for NT. Journal of Nanoparticle Research, 10(5), 715-728. ISSN 1388-0764.

[44] RAESFELD, A., P. GEURTS, M. JANSEN, J. BOSHUIZEN a R. LUTTGE, 2012. Influence of partner diversity on collaborative public R\&D project outcomes: A study of application and commercialization of nanotechnologies in the Netherlands. Technovation, 32(3-4), 227-233. ISSN 0166-4972.

[45] ROCO, M. C., 2011. The long view of NT development: The National NT Initiative at 10 years. Journal of Nanoparticle Research, 13(2), 427-445. ISSN 1388-0764. 
[46] SASTRY, K., H. B. RASHMI a N. H. RAO, 2010. NT patents as R\&D indicators for disease management strategies in agriculture. Journal of Intellectual Property Rights, 15, 197-205. ISSN 0971-7544.

[47] SCHELLEKENS, M., 2008. Patenting NT in Europe: Making a Good Start? An Analysis of Issues in Law and Regulation. Tilburg University Legal Studies Working Paper, No. 008/2008 [on-line]. [cit 22. 2. 2015]. Dostupné z: http://papers.ssrn.com/sol3/papers.cfm?abstract_id $=1139080$

[48] SCHEU, M., V. VEEFKIND, Y. VERBANDT, E. M. GALAN, R. ABSALOM a W. FÖRSTER, 2006. Mapping NT patents: The EPO approach. World Patent Information, 28(3), 204-211. ISSN 0172-2190.

[49] SCHMOCH, U. a A. THIELMANN, 2012. Cyclical long-term Development of Complex Technologies - Premature Expectations in NT? Fraunhofer ISI Discussion Papers Innovation Systems and Policy Analysis, No. 31. ISSN 1612-1430.

[50] SOVVA, 2013. Výskum v oblasti nanovied a nanotechnológií. SOVVA [on-line]. [cit 29. 9. 2014]. Dostupné z: http://sovva.sk/aktuality/zodpovedny-vyskum-v-oblastinanovied-a-nanotechnologii

[51] TRACHANA, V., 2013. Austerity-led brain drain is killing Greek science. Nature [online]. [cit 25. 6. 2014]. Dostupné z: http://www.nature.com/news/austerity-led-braindrain-is-killing-greek-science-1.12813

[52] UN, 2014a. National Accounts Main Aggregates Database. UN [on-line]. [cit 3. 3. 2015]. Dostupné z: http://unstats.un.org/unsd/snaama/dnllist.asp

[53] UN, 2014b. The World Population Situation in 2014. UN [on-line]. [cit 7. 3. 2015]. Dostupné z: http://www.un.org/en/development/desa/population/publications/pdf/ trends/Concise \%20Report\%20on\%20the\%20World\%20Population\%20Situation\%20201 4/en.pdf

[54] UPVSR, 2013. Medzinárodné patentové triedenie. UPVSR [on-line]. [cit 11. 5. 2014]. Dostupné $\quad \mathrm{z}: \quad \mathrm{http} / / / \mathrm{ipc}$.indprop.gov.sk/ipcpub/\#refresh=page\&lang=sk\&menulang $=$ SK\&indexes $=$ yes $\&$ notion $=$ scheme $\&$ version $=20130101 \&$ symbol $=\mathrm{B}$

[55] USPTO, 2014. Patents. USPTO [on-line]. [cit 25. 3. 2014]. Dostupné z: http://www.uspto.gov/inventors/patents.jsp\#heading-3

[56] WANG, G. a J. GUAN, 2010. The role of patenting activity for scientific research: A study of academic inventors from China's NT. Journal of Informetrics, 4(3), 338-350. ISSN 1751-1577.

[57] WARTBURG, I. a T. TEICHERT, 2008. Valuing patents and licenses from a business strategy perspective - Extending valuation considerations using the case of nanotechnology. World Patent Information, 30(2), 106-114. ISSN 0172-2190.

[58] WIPO, 2012. Nano-technology. The World Intellectual Property Organization [on-line]. [cit 17. 3. 2014]. Dostupné z: http://www.wipo.int/classifications/ fulltext/new_ipc/ipc7/eb82b.htm

[59] WOLF, E. L. a M. MEDIKONDA, 2012. Understanding the Nanotechnology Revolution. Chichester: Wiley-VCH, 1. edition. ISBN 978-3527411092. 